\title{
Carrier detection in childhood: a need for policy reform
}

\author{
Lainie Friedman Ross*
}

\begin{abstract}
Current policy statements discourage identification of disease carrier status in minors on the grounds that carrier information is of mainly reproductive significance. Such policies fail to consider that the carrier state may have important health implications for minors. They also fail to consider that carrier status of newborns is routinely discovered as an incidental finding in newborn screening programs. Finally, such policies fail to take into account that it may not be parents but adolescents who are seeking out this information and that adolescence may be a valid time to learn about one's reproductive risks. Here, I consider the issues that need to be addressed in revising current policies about the carrier detection of minors.
\end{abstract}

\section{Carrier identification in newborn screening}

In 1994, the UK Clinical Genetics Society published a report in which it stated that 'the working party would make a presumption against testing children to determine their carrier status, where this would be of purely reproductive significance to the child in the future'[1]. The following year, the American Society of Human Genetics and the American College of Medical Genetics issued a joint statement in which they came to the same conclusion: 'If the medical or psychosocial benefits of a genetic test will not accrue until adulthood, as in the case of carrier status or adult-onset diseases, genetic testing generally should be deferred' [2].

Neither of these statements considered the fact that the most common genetic screening program in pediatrics, newborn screening (NBS), was (or would soon) routinely identify carriers. NBS for phenylketonuria began in the 1960s in both countries and hypothyroidism was added in the 1970s in the US and in 1981 in the UK. Both were

*Correspondence: Iross@uchicago.edu

Department of Pediatrics, University of Chicago, 5841 S Maryland Ave, MC 6082, Chicago, IL 60637, USA conditions for which early treatment existed. Following the discovery that penicillin prophylaxis would reduce mortality in infants with sickle cell disease (SCD), a 1987 National Institute of Health (USA) consensus conference recommended universal NBS for hemoglobinopathies [3]. By 1994, 42 US states were screening for SCD and other hemoglobin variants [4], and the UK would follow within a decade [5]. Virtually all screening methods identify individuals with both SCD and sickle cell trait (SCT, the heterozygous carrier state) [3].

In both countries, an early concern was what to do with the identification of carriers in NBS programs. In its 1994 report, Assessing Genetic Risks [4], the US Institute of Medicine (IOM) stated that newborns should not be screened for the purpose of determining carrier status, but that results obtained incidentally should be reported to the infant's parents. The IOM recommended counseling and consent for NBS because of the routine identification of carriers [4].

The main argument to support voluntary consent for NBS is based on the great deference that our society gives to parents about how they raise their children [6,7]. Parents are given wide discretion in medical decisionmaking, with the threshold for state intervention based on whether a parent's action is abusive or neglectful $[6,7]$. Given that the likelihood of a true positive NBS is rather low, parental refusal does not fall into the category of abuse or neglect. The legitimacy of a mandatory program is further challenged as NBS expands beyond conditions for which early treatment is known to be highly effective [8]. In addition, there is growing parental concern about the use of residual blood spots for research when the parents have not provided consent [9].

\section{Carrier status and its health implications}

Traditionally, carriers of autosomal recessive conditions were presumed to be healthy and carrier status was presumed to have mainly reproductive implications. However, in the case of SCT, the data suggest otherwise. In a 1978 review, Sears [10] found convincing evidence that SCT was associated with hyposthenuria (decreased ability to concentrate urine), renal hematuria or bacteriuria (blood or bacteria in the urine), pyelonephritis 
(kidney inflammation) in pregnancy, and splenic infarction when exposed to hypoxia at high altitudes. Although Sears [10] enumerated many other associations, the evidence was too anecdotal to make any valid conclusions. In a 2009 review, Tsaras et al. [11] found additional definitive associations between SCT and renal medullary cancer, exercise-related sudden death and exertional rhabdomyolysis (muscle breakdown).

SCT is not exceptional; carriers of other conditions have also been found to be at risk for health conditions. For example, 20 to $30 \%$ of female carriers of a dystrophin mutation associated with Duchenne muscular dystrophy develop cardiomyopathies [12], and fragile X pre-mutation carriers are at risk for premature ovarian failure and fragile $\mathrm{X}$ ataxia syndrome [13]. What makes the example of SCT important, however, are the historical lessons to be learned about the unintended psychosocial harms that population carrier screening caused in the 1970s and 1980s, eroding African American trust in the medical community $[4,14]$. Thus, when the National Collegiate Athletic Association (NCAA) announced in 2009 that it would require SCT testing of all college athletes [15], the Sickle Cell Disease Association of America opposed this policy out of concern that identification could lead to discrimination and stigma [16].

The NCAA policy stems from the resolution of a lawsuit with the family of Dale Lloyd II, a college athlete with SCT who died during football practice [15]. The relationship between SCT and exercise-induced death was first raised in military basic training in 1970 [17], and two large studies in the 1980s and 1990s confirmed that recruits with SCT were at increased risk of exerciseinduced death $[18,19]$. Minor changes in basic training programs, however, have been effective in reducing the number of deaths from SCT in basic training (Gary Crouch, personal communication). On the basis of these data, the military no longer screens recruits for SCT, which makes the NCAA policy suspect, particularly given that there is no consensus on how this information is to be used by the universities where these athletes play.

The need for the NCAA policy, however, should be short-lived because by 2020 all college athletes with SCT will have been identified in newborn screening. However, it is not certain that these youngsters will know their results. In 2008, Kavanaugh et al. [20] showed that at least two programs did not report SCT and three states informed only the families but not their health care providers. But even in states in which parents and providers are supposed to be informed, this is not always happening [20]. In the UK, legislation was passed in 2000 to create a national linked registry of prenatal and neonatal SCT to ensure that carrier status data are accessible regardless of how and when they are determined [21].

\section{Adolescent carrier identification}

In 2001, the American Academy of Pediatrics (AAP) published a statement [22] on genetic testing in children. Like the professional statements of the 1990s, the AAP did 'not support the broad use of carrier testing or screening in children or adolescents' [22]. However, the AAP noted that carrier testing may be appropriate for the pregnant adolescent or the adolescent who is planning a pregnancy [22]. In other countries, the practice of carrier identification of adolescents for reproductive planning purposes is more routine. There have been various population-based screening programs of adolescents, for Tay Sachs disease, cystic fibrosis and hemoglobinopathies, in Canada, Australia and the Middle East. Many of these programs were implemented in the school setting because it offers the opportunity to capture a large percentage of adolescents, and the information is well retained [23]. Concerns, however, have been raised that the school setting may not be ideal for ensuring privacy and confidentiality [23]. School-based programs also raise questions about the voluntariness of consent. The consent issues may be even more complicated if such programs were to be replicated in the US, where schoolbased screening may require parental permission.

Data show that many parents support the testing of their children for carrier status before the legal age of majority for a wide array of conditions, including conditions for which population-based screening may not be economically justifiable [24]. The arguments to support carrier testing of minors are: (1) it may be easier to incorporate this information into their life plans; (2) it reduces uncertainty and the resentment expressed when the information is delayed; and (3) the parental moral right, or even moral obligation, to know their child's genetic risks [24]. A survey of social networkers in the US found that $6 \%$ had used the services of a personal genome testing (PGT) company and an additional 64\% indicated that they would consider using them in the future, with the majority interested in carrier testing of someone other than themselves, including their progeny [25]. The respondents were interested in testing despite the fact that less than half were confident that they understood the risks and benefits of PGT [25]. Tabor and Kelley [26] suggest that direct-to-consumer (DTC) PGT companies should accept some moral responsibility to educate parents about the risks and benefits of testing their children, to encourage parents to opt out of receiving carrier test data for rare genetic traits 'particularly if they have no reason to be concerned about increased family risk', and to provide genetic counseling to avoid misunderstandings. Three additional issues have not been adequately addressed with respect to DTC PGT. First is whether there is an obligation by parents or DTC PGT companies to ensure that the minors have access to this 
information, whether during childhood or when they reach adulthood. Second, empirical data are needed on how to ensure that the carrier information is transferred in a way that promotes understanding and minimizes the harms that such information may cause. Third, conceptual analyses are needed to examine whether adolescents should be able to seek DTC PGT alone or whether parental permission should be required, and how this could be enforced.

\section{Conclusions}

Current policy statements on carrier testing of minors focus on why parents want this reproductive information and do not fully consider other health implications that carrier status may confer, nor the value of carrier identification for the maturing minors themselves. The statements also fail to provide an analytical framework regarding whose consent is needed. Currently, there is no consensus on whether minors should be able to consent for themselves for carrier testing or whether parental permission is necessary, although neonates are routinely identified through NBS without any consent. There is also no consensus about the appropriate venues for carrier testing of minors - whether it should be restricted to the clinics or permitted in schools or at home. Policy recommendations about carrier testing of children need to be re-examined.

\section{Abbreviations}

AAP, American Academy of Pediatrics; DTC, direct-to-consumer; IOM, Institute of Medicine; NBS, newborn screening; NCAA, National Collegiate Athletic Association; PGT, personal genome testing; SCD, sickle cell disease; SCT, sickle cell trait.

\section{Competing interests}

The author declares that she has no competing interests.

\section{Published: 22 April 2010}

\section{References}

1. Working Party of the Clinical Genetics Society (UK): The genetic testing of children. J Med Genet 1994, 31:785-797.

2. American Society of Human Genetics (ASHG)/American College of Medical Genetics (ACMG): Points to consider: ethical, legal, and psychosocial implications of genetic testing in children and adolescents. Am J Hum Genet 1995, 57:1233-1241.

3. National Institutes of Health Consensus Development Panel: Newborn screening for sickle cell disease and other hemoglobinopathies. JAMA 1987, 258:1205-1209.

4. Andrews L, Fullarton J, Holtzman N, Motulsky G (eds) for the Institute of Medicine: Assessing Genetic Risks: Implications for Health and Social Policy. Washington DC: National Academy Press; 1994.

5. Musson V, Rogers J: Report of the Independent Interim Evaluation of The Sickle Cell and Thalassaemia Screening Programme in England. Cambridge: Jill Rogers
Associates and Liberating Solutions; 2009. [http://sct.screening.nhs.uk/ professional-resources]

6. Buchanan A, Brock D: Deciding for Others: The Ethics of Surrogate Decision Making. New York: Cambridge University Press; 1989.

7. Ross LF: Children, Families, and Health Care Decision-making. Oxford: Oxford University Press; 1998.

8. President's Council on Bioethics: The Changing Moral Focus of Newborn Screening. Washington DC: Government Printing Office; 2008.

9. Citizens' Council on Health Care: News Releases [http://www.cchconline. org/pressreleases.php3]

10. Sears DA: The morbidity of sickle cell trait: a review of the literature. Am J Med 1978, 64:1021-1036.

11. Tsaras G, Owusu-Ansah A, Boateng FO, Amoateng-Adjepong Y: Complications associated with sickle cell trait: a brief narrative review. Am $J$ Med 2009, 122:507-512.

12. Politano L, Nigro V, Nigro G, Petretta VR, Passamano L, Papparella S, Di Somma $\mathrm{S}$, Comi LI: Development of cardiomyopathy in female carriers of Duchenne and Becker muscular dystrophies. JAMA 1996, 275:1335-1338.

13. Hagerman PJ, Hagerman RJ: The Fragile-X premutation: a maturing perspective. Am J Hum Genet 2004, 74:805-816.

14. Wailoo K, Pemberton S: The Troubled Dream of Genetic Medicine. Baltimore MD: Johns Hopkins University Press; 2006.

15. NCAA: Testing recommended for Sickle Cell Trait status. NCAA News 29 June 2009 [http://www2.ncaa.org/wps/ncaa?key=/ncaa/ncaa/ncaa+news/ ncaa+news+online/2009/association-wide/testing+recommended+for+sickl e+cell+trait+status_06_29_09_ncaa_news]

16. Sickle Cell Disease Association of America: Press release regarding NCAA recommendations [http://www.sicklecelldisease.org/docs/CMO\%20 Press\%20Release\%20-\%20Sickle\%20Cell\%20Trait\%20and\%20NCAA.pdf]

17. Jones SR, Binder RA, Donowho EM: Sudden death and sickle-cell trait. NEngl J Med 1970, 282:323-325.

18. Kark JA, Posey DM, Schumacher HR, Ruehle CJ: Sickle cell trait as a risk factor for sudden death in physical training. New Eng/ J Med 1987, 317:781-787.

19. Drehner D, Neuhauser KM, Neuhasuer TS, Blackwood GV: Death among US Air force basic trainees 1956-1996. Mil Med 1999, 164:841-847.

20. Kavanaugh PL, Wang CJ, Therrell BL, Sprinz PG, Bauchner H: Communication of positive newborn screening results for sickle cell disease and sickle cell trait: variation across states. Am J Med Genet 2008, 148C:15-22.

21. Department of Health (United Kingdom): The NHS Plan. A Plan for Investment. A Plan for Reform. London: The Stationery Office; 2000. [http://www.dh.gov. uk/prod_consum_dh/groups/dh_digitalassets/@dh/@en/documents/ digitalasset/dh_4055783.pdf]

22. American Academy of Pediatrics (AAP) Committee on Bioethics: Ethical issues with genetic testing in pediatrics. Pediatrics 2001, 107:1451-1455.

23. Ross LF: Heterozygote carrier testing in high schools abroad: what are the lessons for the U.S.? J Law Med Ethics 2006, 34:753-764.

24. Borry P, Evers-Kiebooms G, Cornel MC, Clarke A, Dierickx K on behalf of the Public and Professional Policy Committee (PPPC) of the European Society of Human Genetics: Genetic testing in asymptomatic minors. Eur J Hum Genet 2009, 17:711-719.

25. McGuire AL, Diaz CM, Wang T, Hilsenbeck SG: Social networkers' attitudes toward direct-to-consumer personal genome testing. Am J Bioeth 2009, 9:3-10.

26. Tabor HK, Kelley M: Challenges in the use of direct-to-consumer personal genome testing in children. Am J Bioeth 2009, 9:32-34.

\section{doi:10.1186/gm146}

Cite this article as: Ross LF: Carrier detection in childhood: a need for policy reform. Genome Medicine 2010, 2:25. 